\title{
THE EFFECT OF ACTH AND PATHOLOGICAL INCREASES IN ADRENAL CORTICAL FUNCTION ON URINARY ALPHA- KETOLIC STEROID METABOLITES ${ }^{1}$
}

\author{
By F. C. DOHAN, J. C. TOUCHSTONE, AND E. M. RICHARDSON WITH THE TECHNICALTIF REE EMI \\ ASSISTANCE OF HELEN BULASCHENKO, IRMGARD LANDOLT, AND \\ WALTER APPLIN
}

(From the Endocrine Section of the William Pepper Laboratory of Clinical Medicine, University of Pennsylvania, and the Department of Medicine, School of Medicine, University of Pennsylvania, Philadelphia, Pa.)

(Submitted for publication October 11, 1954; accepted November 17, 1954)

Previous studies (1) have shown that the specific alpha-ketolic steroid metabolites found in the urine after administration of a known alphaketolic steroid reflect, to a limited extent, the nature of the precursor. With this study as a baseline, we have determined the major urinary alphaketolic steroid metabolites found after intravenous infusion of human subjects with ACTH, and some of those found in the urine of a man with Cushing's syndrome, and in that of a woman with metastatic adrenocortical carcinoma. The results of this study and some speculations concerning the possible nature and rate of alpha-ketolic steroid secretion are presented in this paper.

\section{METHODS}

Methods employed and their limitations have been presented previously (1). Terminology has been previously discussed (1). The abbreviations employed are indicated in Table I. The commonly employed letter designations (Kendall's compounds F, E, B, and A; Reichstein's S and DOC) have been used with the addition that $H_{4}$ indicates the tetrahydro compound (Pregnane-3 $\alpha-o l$ ) and $\mathrm{H}_{2}$ indicates the "dihydro compound" (Pregnane-3-one). Glucuronidase, 100 units per $\mathrm{ml}$. of urine, was employed for hydrolysis. (It is now recognized that this is insufficient for maximum hydrolysis and hence for maximum yield.) After glucuronidase hydrolysis, the urine was extracted at $\mathrm{pH} 1$ with $\mathrm{CHCl}_{3}$ for one hour on an oscillating shaker. Paper chromatographic separation was accomplished primarily by using the toluene-propylene glycol system of Burton, Zaffaroni, and Keutmann (2). After development of the chromatogram, the absorption of ultra-violet light of the paper strip at $245 \mathrm{~m} \mu$ was determined directly in a Beckman DU spectrophotometer

1 This investigation was supported in part by research grant H-922 from the National Heart Institute, of the National Institutes of Health, Public Health Service; and by grants from the American Heart Association, the Helon Augusta Parkhill Memorial Fund, Eli Lilly and Company and the Ciba Pharmaceutical Products, Inc. by means of an adaptor (3). Absorption at $600 \mathrm{~m} \mu$ was similarly determined after spraying with blue tetrazolium to determine the presence of alpha-ketolic compounds. The results were plotted against distance from the starting line on the chromatogram as shown in Figures 1 and 3. Semi-quantitative estimation of the alpha-ketolic steroid metabolites (AKSM) is possible using the areas of the peaks (1).

Identification technics for those zones (peaks) which were rechromatographed in various solvent systems and isolated are indicated in Table $I$. A critique of these identification procedures and sources of authentic sample steroids have been presented (1). The unmodified term identification is employed only for those substances which have been isolated and subjected to the battery of tests previously described (1) including spectrometry in sulfuric acid or infrared spectrometry or both. All infrared analyses were done through the courtesy of Dr. Thomas F. Gallagher or of the late Dr. Konrad Dobriner, at the Sloan-Kettering Institute for Cancer Research, Memorial Center, New York. Reducing lipid-soluble substances were determined by the method of Heard, Sobel, and Venning (4) after acid hydrolysis (Ac. R-L) and after glucuronidase followed by acid hydrolysis (G'ase R-L) as previously described (1). The total neutral $17-$ ketosteroids (17-KS) were determined by a modification of the method of Holtorff and Koch (5).

\section{RESULTS}

\section{Part I. Effects of ACTH}

1. Identification studies. Figure 1 shows the effects upon urinary alpha-ketolic steroid excretion of ACTH administered intravenously to four human subjects. The identified peaks are indicated by diagonal lines. The identification procedures are listed in Table I, and semi-quantitative estimations of the "24-hour excretion" of the identified and some only partially identified alphaketolic metabolites in Table II. In the most polar fraction (X), the peaks in the $\mathrm{H}_{4} \mathrm{~F}$ and $\mathrm{H}_{4} \mathrm{E}$ positions are apparent in all four individuals. These 
TABLE I

Urinary alpha-ketolic steroid metabolites: identification studies *,

\begin{tabular}{|c|c|c|c|c|c|c|c|c|}
\hline Pt. & $\begin{array}{l}\text { Frac- } \\
\text { tion } \\
\text { and } \\
\text { peak } \\
\text { no. }\end{array}$ & $\begin{array}{l}\text { Standard steroid } \\
\text { Compound isolated }\end{array}$ & $\begin{array}{c}\quad \mathbf{R D} \\
\underset{\substack{\text { P.G. } \\
\text { (free) }}}{\text { Toluene/ }}\end{array}$ & $\begin{array}{l}\text { DOc } \\
\text { Me. } \\
\text { cyclo- } \\
\text { hexane/ } \\
\text { P.G. } \\
\text { (acetate) }\end{array}$ & $\begin{array}{l}\text { U.V. } \\
\text { abeorb. } \\
245 \text { m. }\end{array}$ & $\begin{array}{l}\text { Porter- } \\
\text { Silber }\end{array}$ & $\begin{array}{l}\text { Maxima spectra } \\
\text { in } \mathrm{H}_{2} \mathrm{SO}_{4}\end{array}$ & Other \\
\hline \multicolumn{9}{|c|}{ After I.V. ACTH } \\
\hline \multirow[t]{8}{*}{ HI. } & $\mathbf{X}_{1}$ & $\begin{array}{c}\text { Pregnane-3 } \alpha, 11 \beta, 17 \alpha, 21 \text {-tetrol-20-one }\left(\mathrm{H}_{4} \mathrm{~F}\right) \\
\text { Ditto }\end{array}$ & .0060 & .19 & $\begin{array}{l}\mathbf{0} \\
\mathbf{0}\end{array}$ & + & $\begin{array}{llll}260 & 330 & 415 & 515 \\
252 & 320 & 410 & 510\end{array}$ & $\begin{array}{l}\text { Red color with } \mathrm{H}_{2} \mathrm{SO} \text {, } \\
\text { and ethyl acetate }\end{array}$ \\
\hline & $X_{2}$ & $\begin{array}{c}\text { Pregnane-3 } \alpha, 17 \alpha, 21 \text {-triol-11, 20-dione }\left(H_{4} E\right) \\
\text { Ditto }\end{array}$ & $\begin{array}{l}.0085 \\
.0095\end{array}$ & .40 & $\begin{array}{l}\mathbf{0} \\
\mathbf{0}\end{array}$ & + & $\begin{array}{lll}270 & 335 & 410 \\
268 & 320 & 410\end{array}$ & \\
\hline & $X_{3}$ & $\Delta^{4}$-pregnene-11 $, 17 \alpha, 21$-triol-3, 20-dione (F) & $\begin{array}{l}.017 \\
.015\end{array}$ & & + & & & $\begin{array}{l}\text { Fluorescence } \\
\text { Fluorescence }\end{array}$ \\
\hline & $x_{4}$ & $\begin{array}{l}\Delta^{4} \text {-pregnene-17 } \alpha, 21 \text {-diol-3, 11, 20-trione (E) } \\
\text { Ditto }\end{array}$ & $\begin{array}{l}.041 \\
.035\end{array}$ & & + & + & & \\
\hline & $\mathrm{X}_{\mathbf{5}}$ & $\begin{array}{c}\left.\text { Pregnane-3a, } 17 \alpha, 21 \text {-triol-20-one ( } \mathrm{H}_{4} \mathrm{~S}\right) \\
\text { Ditto ? (see text) }\end{array}$ & & $\begin{array}{l}3.8 \\
4.6 \\
\end{array}$ & $\begin{array}{l}\mathbf{0} \\
\mathbf{0}\end{array}$ & + & $\begin{array}{ll}315 & 410 \\
310 & 410 \\
\end{array}$ & \\
\hline & $\mathbf{Y}_{1}$ & $\begin{array}{l}\text { Pregnane-3 } \alpha, 11 \beta, 21-\text {-triol-20-one }\left(\mathrm{H}_{4} \mathrm{~B}\right) \\
\text { Ditto }\end{array}$ & $\begin{array}{l}.066 \\
.067\end{array}$ & $\begin{array}{l}3.2 \\
2.6\end{array}$ & $\begin{array}{l}\mathbf{0} \\
\mathbf{0}\end{array}$ & $\begin{array}{l}\mathbf{0} \\
\mathbf{0}\end{array}$ & $\begin{array}{ll}310 & 415 \\
310 & 415\end{array}$ & \\
\hline & $Y_{2}$ & 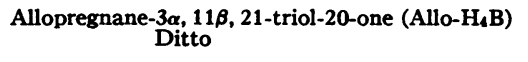 & .11 & $\begin{array}{l}2.9 \\
2.6\end{array}$ & $\begin{array}{l}\mathbf{0} \\
\mathbf{0}\end{array}$ & & $\begin{array}{l}320410 \\
310420\end{array}$ & \\
\hline & $\mathbf{Y}_{3}$ & $\begin{array}{l}\text { Pregnane-3 } \alpha, 21-\text { diol-11, 20-dione (H,A) } \\
\text { Ditto }\end{array}$ & .14 & $\begin{array}{l}5.6 \\
6.5 \\
\end{array}$ & $\begin{array}{l}\mathbf{0} \\
\mathbf{0}\end{array}$ & & & \\
\hline \multirow{2}{*}{$\begin{array}{l}\text { HI. } \\
\text { and } \\
\text { ME. } \\
\text { Com- } \\
\text { bined }\end{array}$} & $\mathbf{Z}_{1}$ & $\begin{array}{c}\Delta^{4} \text {-pregnene-11ß, 21-diol-3, 20-dione (B) } \\
\text { Ditto }\end{array}$ & $:$ & .14 & + & & $\begin{array}{llll}280 & 320 & 370 & 445 \\
286 & 320 & 372 & 450\end{array}$ & $\begin{array}{l}\text { Fluorescence } \\
\text { Fluorescence }\end{array}$ \\
\hline & $\mathbf{Z}_{\mathbf{2}}$ & $\begin{array}{l}\text { Unknown } \\
\Delta^{4} \text {-pregnene-21-ol-3, 11, 20-trione (A) } \\
\text { Ditto ? (see text) }\end{array}$ & b & $\begin{array}{r}5.1 \\
.52 \\
.40 \\
\end{array}$ & $\begin{array}{l}\mathbf{0} \\
+ \\
+\end{array}$ & 0 & & \\
\hline \multirow[t]{7}{*}{$\overline{\overline{\text { ME. }}}$} & $\mathbf{X}_{1}$ & $\begin{array}{c}\text { Pregnane-3 } \alpha, 11 \beta, 17 \alpha, 21 \text {-tetrol-20-one }\left(\mathrm{H}_{4} \mathrm{~F}\right) \\
\text { Ditto }\end{array}$ & .0060 & $\begin{array}{l}.19 \\
.19\end{array}$ & $\begin{array}{l}\mathbf{0} \\
\mathbf{0}\end{array}$ & + & $\begin{array}{llll}260 & 330 & 415 & 515 \\
260 & 330 & 410 & 510\end{array}$ & $\begin{array}{l}\text { Red color with } \mathrm{H}_{2} \mathrm{SO}_{4} \\
\text { and ethyl acetate }\end{array}$ \\
\hline & $\mathrm{X}_{2}$ & $\begin{array}{c}\text { Pregnane-3 } \alpha, 17 \alpha, 21 \text {-triol-11, 20-dione }\left(\mathrm{H}_{4} \mathrm{E}\right) \\
\text { Ditto }\end{array}$ & .0085 & $\begin{array}{l}.40 \\
.35\end{array}$ & $\mathbf{0}$ & + & $\begin{array}{lll}270 & 335 & 410 \\
270 & 315 & 410\end{array}$ & \\
\hline & $X_{3}$ & $\begin{array}{c}\Delta^{4} \text {-pregnene-11 } \beta, 17 \alpha, 21 \text {-triol-3, 20-dione (F) } \\
\text { Ditto }\end{array}$ & d & & + & + & $\begin{array}{llll}240 & 280 & 390 & 475 \\
240 & 284 & 375 & 480\end{array}$ & $\begin{array}{l}\text { Fluorescence } \\
\text { Fluorescence }\end{array}$ \\
\hline & $\mathbf{X}_{4}$ & $\begin{array}{c}\Delta^{L} \text {-pregnene-17a, 21-diol-3, 11, 20-trione (E) } \\
\text { Ditto }\end{array}$ & $\begin{array}{l}.041 \\
.036 \\
\end{array}$ & $\bullet$ & + & + & & \\
\hline & $\mathbf{Y}_{1}$ & $\begin{array}{l}\text { Pregnane-3 } \alpha, \text { 11 } \beta, 21 \text {-triol-20-one (H4B) } \\
\text { Ditto }\end{array}$ & $\begin{array}{l}.066 \\
.054\end{array}$ & $\begin{array}{l}3.2 \\
2.8\end{array}$ & $\begin{array}{l}\mathbf{0} \\
\mathbf{0}\end{array}$ & & $\begin{array}{ll}310 & 415 \\
310 & 420\end{array}$ & $\begin{array}{l}\text { Infrared } \\
\text { Infrared }\end{array}$ \\
\hline & $Y_{2}$ & 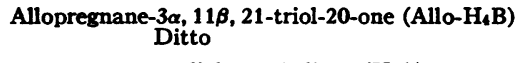 & .11 & $\begin{array}{l}2.9 \\
2.4\end{array}$ & $\mathbf{0}$ & & $\begin{array}{l}320410 \\
310430\end{array}$ & $\begin{array}{l}\text { Infrared } \\
\text { Infrared }\end{array}$ \\
\hline & $Y_{3}$ & $\begin{array}{c}\text { Pregnane-3 } \alpha, 21 \text {-diol-11, 20-dione (H^A) } \\
\text { Ditto }\end{array}$ & $\begin{array}{r}.14 \\
.19 \\
\end{array}$ & $\begin{array}{l}5.6 \\
5.7 \\
\end{array}$ & $\begin{array}{l}\mathbf{0} \\
\mathbf{0} \\
\end{array}$ & & $\begin{array}{lll}290 & 350 & 415 \\
292 & 345 & 410 \\
\end{array}$ & $\begin{array}{l}\text { Infrared } \\
\text { Infrared }\end{array}$ \\
\hline \multirow[t]{3}{*}{ MUR. } & $\mathbf{X}_{1}$ & $\begin{array}{c}\text { Pregnane-3 } \alpha, 11 \beta, 17 \alpha, 21 \text {-tetrol-20-one (HAF) } \\
\text { Ditto }\end{array}$ & .0060 & & $\begin{array}{l}\mathbf{0} \\
\mathbf{0}\end{array}$ & & & $\begin{array}{l}\text { Red color with } \mathrm{H}_{2} \mathrm{SO}_{4} \\
\text { and ethyl acetate }\end{array}$ \\
\hline & $\mathbf{X}_{2}$ & $\begin{array}{c}\text { Pregnane-3 } \alpha, 17 \alpha, 21 \text {-triol-11, 20-dione }\left(\mathrm{H}_{4} \mathrm{E}\right) \\
\text { Ditto }\end{array}$ & $\begin{array}{l}.0085 \\
.0084\end{array}$ & & $\begin{array}{l}\mathbf{0} \\
\mathbf{0}\end{array}$ & & & $\begin{array}{l}\text { Infrared } \\
\text { Infrared }\end{array}$ \\
\hline & $X_{3}$ & $\begin{array}{l}\Delta^{4} \text {-pregnene-11 } \beta, 17 \alpha, 21 \text {-triol-3, 20-dione (F) } \\
\text { Ditto }\end{array}$ & $\begin{array}{r}.017 \\
.017 \\
\end{array}$ & & + & & & \\
\hline
\end{tabular}

\begin{tabular}{|c|c|c|}
\hline \multirow[t]{5}{*}{ MUS. } & $\mathbf{X}_{\mathbf{1}}$ & $\begin{array}{c}\text { Pregnane-3 } \alpha, 11 \beta, 17 \alpha, 21 \text {-tetrol-20-one (H/F) } \\
\text { Ditto }\end{array}$ \\
\hline & $X_{2}$ & $\begin{array}{c}\text { Pregnane-3 } \alpha, 17 \alpha, 21-\text { triol-11, 20-dione }\left(\mathrm{H}_{4} \mathrm{E}\right) \\
\text { Ditto }\end{array}$ \\
\hline & $X_{2}$ & $\underset{\text { Ditto }}{\Delta \text {-pregnene-11 }}, 17 \alpha, 21$-triol-3, 20-dione (F) \\
\hline & $X_{4}$ & $\begin{array}{c}\Delta \text {-pregnene-17 } \alpha, 21 \text {-diol-3, 11, 20-trione (E) } \\
\text { Ditto }\end{array}$ \\
\hline & $\mathbf{X}_{\mathbf{6}}$ & 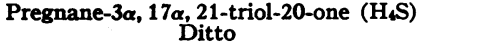 \\
\hline
\end{tabular}

\begin{tabular}{|c|c|c|}
\hline \multirow[t]{4}{*}{ CA. } & $\mathbf{X}_{1}$ & $\begin{array}{c}\text { Pregnane-3 } \alpha, 11 \beta, 17 \alpha, 21 \text {-tetrol-20-one (H,F) } \\
\text { Ditto }\end{array}$ \\
\hline & $\mathbf{X}_{2}$ & $\begin{array}{c}\text { Pregnane-3 } \alpha, 17 \alpha, 21-\text { triol-11, 20-dione }\left(\mathrm{H}_{4} \mathrm{E}\right) \\
\text { Ditto }\end{array}$ \\
\hline & $\mathbf{X}_{6}$ & $\begin{array}{c}\text { Pregnane-3 } \alpha, 17 \alpha, 21-\text { triol-20-one (H/S) } \\
\text { Ditto }\end{array}$ \\
\hline & $\mathbf{Y}_{4}$ & $\begin{array}{c}\Delta^{4} \text {-pregnene-17 } \alpha, 21 \text {-diol-3, 20-dione (S) } \\
\text { Ditto ? (see text) }\end{array}$ \\
\hline
\end{tabular}

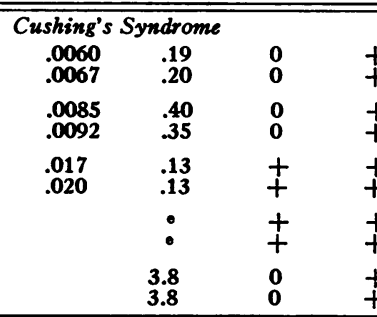

+ 260330415515
$+\quad 260315415510$
$+\quad 270335410$
$+\quad 264320410$
+

Red color with $\mathrm{H}_{2} \mathrm{SO}_{3}$ and ethyl acetate

Fluorescence Fluorescence

280340415

280340410

$+\quad 310410 \quad$ Infrared

\begin{tabular}{|c|c|c|c|c|c|}
\hline \multicolumn{6}{|c|}{ Adenocortical Cancer } \\
\hline $\begin{array}{l}.0060 \\
.0054\end{array}$ & & $\begin{array}{l}\mathbf{0} \\
\mathbf{0}\end{array}$ & + & $\begin{array}{llll}260 & 330 & 415 & 515 \\
260 & 330 & 410 & 510\end{array}$ & $\begin{array}{l}\text { Red color with } \mathrm{H}_{2} \mathrm{SO} \\
\text { and ethyl acetate }\end{array}$ \\
\hline $\begin{array}{l}.0085 \\
.0085\end{array}$ & $\begin{array}{l}.40 \\
.33\end{array}$ & $\begin{array}{l}\mathbf{0} \\
\mathbf{0}\end{array}$ & + & $\begin{array}{lll}270 & 335 & 410 \\
276 & 318 & 410\end{array}$ & \\
\hline \multirow[t]{2}{*}{$\begin{array}{l}.036 \\
.032\end{array}$} & $\begin{array}{l}3.8 \\
3.8\end{array}$ & $\begin{array}{l}\mathbf{0} \\
\mathbf{0}\end{array}$ & & $\begin{array}{ll}310 & 410 \\
310 & 400\end{array}$ & $\begin{array}{l}\text { Infrared } \\
\text { Infrared }\end{array}$ \\
\hline & $\begin{array}{l}.15 \\
.16\end{array}$ & + & + & & Red color with $\mathrm{H}_{2} \mathrm{SO}_{4}$ \\
\hline
\end{tabular}

a. RDoc free alcohol in methylcyclohexane/propylene glycol .022; B - RDOc .015.

b. RDoc free alcohol in methylcyclohexane/propylene glycol .034; reference not available.

b. RDOc free alcohol in methylcyclohexane/propylene glycol .034; reference not a
c. RDOo free alcohol in methylcyclohexane/propylene glycol .06; $A-R D O 0.075$.

c. RDOo free alcohol in methylcyclohexane/propylene glycol .06;

e. RDoo acetate in toluene/propylene glycol .30; $\mathrm{E}$ acetate -.31 DOC. The numbers (e.s., $\mathrm{X}_{\mathrm{U}}$ ) listed in the left hand column correspond to those in Figures 1 and 3 . RDoc = Mobility of compound compared to

The RDoo was determined as the alcohol in the toluene-propylene glycol system (P.G.) or as the acetate in the methylcyclohexane-propylene glycol system. Ultraviolet absurption at $245 \mathrm{~m} \mu$ was determined quantitatively directly on the paper and the quantitative reaction with phenylhydrazine of eluates by a modification of the Porter-Silber method. Spectrometry in sulfuric acid and fluorescence tests were also done guantitatively as previously discussed (1). Infrared spectrometry was done at the Sloan-Kettering Institute for Cancer Research, Memorial Center, New York, through the courtesy of Dr. Thomas F. Gallagher and of the late Dr. Konrad Dobriner. For comments concerning criteria of identification, see reference number one. 
have been identified in the case of subjects HI., ME., and MUR. after ACTH. It is evident from this and previous studies (1) as well as the position and relatively small absorption at $245 \mathrm{~m} \mu$ (not shown) in these regions that the twin alphaketolic peaks in the first portion of fraction $\mathrm{X}$ in the other subjects are probably formed by $\mathrm{H}_{4} \mathrm{~F}$ and $\mathrm{H}_{4} \mathrm{E}$. The increased excretion of hydrocortisone (F) after administration of ACTH is also indicated.

Two or more alpha-ketolic steroids are frequently found at the cortisone (E) position as shown by rechromatography. In HI. approximately 20 per cent of this peak is possibly the tetrahydro form of Reichstein's compound S, i.e., $\mathrm{H}_{4} \mathrm{~S}$. However, the possibility exists that the substance may be the $\Delta 9-11$ unsaturated compound which might arise as a dehydration product of $\mathrm{H}_{4} \mathrm{~F}$. This is considered possible since the dehydration product of $11 \beta$-hydroxyandrosterone $(\Delta 9-11$ androstenolone) has been found by Lieberman, Mond, and Smyles (6) after chromatography of urine extracts on alumina. In this instance, extractions were made for 48 hours by the continuous ether method at $\mathrm{pH} 5$, after glucuronidase hydrolysis. The extraction method used by us exposed the urinary steroids to $\mathrm{pH} 1$ for one hour. Since not enough material was available to permit infrared spectrometry and the $\Delta 9-11$ compound has not been available for testing the running rates and the absorption spectrum in sulfuric acid, this possibility cannot be definitely excluded. However, it seems possible that this is, in fact, $\mathrm{H}_{4} \mathrm{~S}$ since the compound has the same characteristics as material identified by infrared spectrometry in extracts of urine from a subject with Cushing's syndrome (MUS.) and from a subject with adrenal cortical carcinoma (CA.) as $\mathrm{H}_{4} \mathrm{~S}$. In addition to the data shown in Table $I$, it has been found that the mobility in the benzene-formamide system of the unknown approximates that of an authentic sample of $\mathrm{H}_{4} \mathrm{~S}$ (See Addendum).

In the mid-polar fraction (Y), peak 1 of subjects $\mathrm{HI}$. and ME. has been identified as tetrahydro $\mathrm{B},\left(\mathrm{H}_{4} \mathrm{~B}\right)(7)$ and peak 3 of fraction $\mathrm{Y}$ of subject $M E$. as tetrahydro $A,\left(H_{4} A\right)(7)$. In addition, the $Y_{2}$ peak of subject ME. has been identified as the allo form of tetrahydro $\mathrm{B}$, (allo- $\mathrm{H}_{4} \mathrm{~B}$ ) (7). Corticosterone (B) has been demonstrated in the urine of the two normal subjects after
ACTH (7). The presence of compound A (11dehydrocorticosterone) was indicated (see Table I) but this compound was not definitely identified (See Addendum).

2. Chromatographic pattern. The chromatographic pattern (Figure 1) must be considered in relation to the effects of variations in technics as well as the proportion of the 24-hour extract employed. However, it is apparent that there is a general similarity of appearance in the chromatograms of extracts of the urine of all four individuals after ACTH. There is also a general similarity in the pre-ACTH patterns. The significance of the increased excretion of " $E$ position" steroids in patient MU. before ACTH is unknown. The alpha-ketolic metabolites in the positions of $\mathrm{H}_{4} \mathrm{~F}$, $\mathrm{H}_{4} \mathrm{E}$, and of compounds $\mathrm{F}$ and $\mathrm{E}$, as well as those in the $\mathrm{Y}$ and $\mathrm{Z}$ chromatographic fractions, are considerably increased by ACTH.

3. Effect of ACTH on urinary excretion of steroids measured by group reactions. The total AKSM (alpha-ketolic steroid metabolites) are increased after ACTH as indicated in Figure 1. The increase in AKSM is relatively greater than in the G'ase R-L (Reducing lipids extractable after glucuronidase plus acid hydrolysis) and considerably so compared to the relative increase of Acid R-L (Reducing lipids after acid hydrolysis only) and the total neutral 17-ketosteroids (17KS) tabulated on the right-hand side of Figure 1. These findings are similar to those shown in Table III of the previous paper (1) after the administration of the "six physiologically active" alpha-ketolic steroids.

Figure 2 shows the distribution of the AKSM by fractions. It includes data from chromatographic analysis of urine from normal individuals not shown in Figure 1. ACTH infusion for eight hours on one day increased the AKSM in all three fractions, but the largest relative increase was found in fraction $Y$.

\section{Comment}

Speculations concerning the nature of the alphaketolic steroid secreted by the adrenal cortex. The urinary alpha-ketolic steroids considered as positively identified by us after infusion of ACTH are: $\mathrm{H}_{4} \mathrm{~F}, \mathrm{H}_{4} \mathrm{E}, \mathrm{F}, \mathrm{H}_{4} \mathrm{~B}$, allo- $\mathrm{H}_{4} \mathrm{~B}, \mathrm{H}_{4} \mathrm{~A}$, and $\mathrm{B}$ (Table I). The first three (plus E) are the major urinary metabolites found after the adminis- 


\section{EFFECT OF ACTH ON CHROMATOGRAPHIC PATTERN OF MAJOR URINARY ALPHA-KETOLIC STEROIDS}

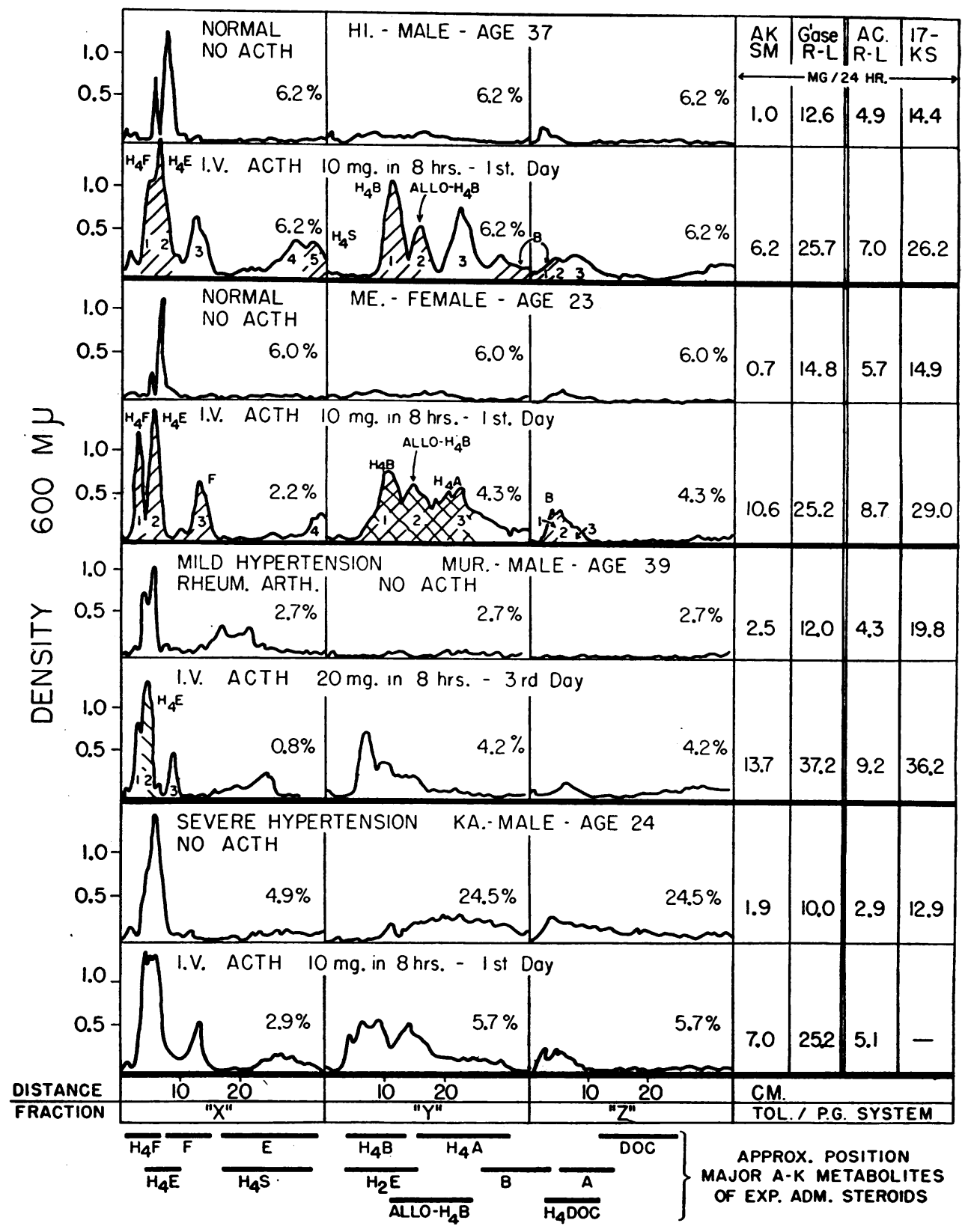

Fig. 1. The Effect of ACTh Infusion upon the Chromatographic Pattern of the Urinary Alpha-Ketolic Steroid Metabolites

The chromatograms were developed in the toluene-propylene glycol system, dried and sprayed with blue tetrazolium. The density of the blue color produced by reaction with alpha-ketolic steroids was then read (by means of an adaptor) directly from the paper in a Beckman DU spectrophotometer at $600 \mathrm{~m} \mu$. The density is charted in relation to the distance from the "starting line" as the abscissa of the horizontal "channels." More than one compound may be in the same region, so that further studies were necessary for isolation. The most polar (X), "mid-polar" (Y), and least polar ( $\mathrm{Z}$ ) fractions are charted. The percentage figures in each fraction indicate the proportion of the 24-hour urine represented by the amount of extract used 
tration of $F$ or $E(1,8-11)$ and the last four are those found in large amounts after administration of compounds B or A $(1,12)$. Cortisone (E), although indicated (Table I), was not positively identified after administration of ACTH but has been positively identified by others (Table III). In addition, the presence of $\mathrm{A}$ and of $\mathrm{H}_{4} \mathrm{~S}$ is suggested by the evidence presented in Table I.

Table III lists the 11 alpha-ketolic steroids that have been positively identified to date in the urine of humans without known adrenocortical disease. Apparently, $\Delta^{5}$-pregnene-3 $\beta, 21$-diol-20-one (13) has not been demonstrated to be a metabolite of these precursors. Aldosterone, present in minute amounts, has been identified in extracts of urine prepared by Luetscher, Wettstein, and Neher (14).

It thus seems probable that the alpha-ketolic steroids secreted by the adrenal cortex in the largest quantities are compounds $\mathrm{F}$ (or E) and B (or A) and possibly smaller amounts of compound $S$. The hydroxyl and keto groups at carbon atom 11 are interconvertible for compounds $F$ and $E(1,8-11)$ and for compounds $B$ and $A$ (1), so the major alpha-ketolic metabolites produced by administration of $\mathrm{F}$ and $\mathrm{E}$ are similar; as are those for $B$ and $A$. Therefore, the exact precursor of the metabolites of these pairs is difficult to determine.

In an attempt to obtain further data bearing on the precursors of the urinary alpha-ketolic metabolites, the amounts of identified and partially identified metabolites found after administration of ACTH and in pathologic adrenocortical hyperfunction have been estimated (Table II). The ratio of the estimated quantities of the various metabolites have been examined and compared to the ratios found after oral administration of $F$ or $\mathrm{E}$ and $\mathrm{B}$ or $\mathrm{A}$ in the previously reported experiments (1). It is recognized that dosage and route of administration may influence the absolute values and the ratios. These limited comparisons, however, do not afford clear-cut evidence indicating that the secretion of $F$ is greater than $\mathrm{E}$; nor that of $\mathrm{B}$ is greater than $\mathrm{A}$.

Evidences from the isolation studies by Romanoff, Hudson, and Pincus (15) of blood from the adrenal vein of a man with prostatic carcinoma would suggest that compound $F$ and compound $B$ are secreted in far greater amounts than the other active alpha-ketolic steroids. In addition, studies of peripheral blood, although of lesser value in determining specific steroid secretion by the adrenal cortex, indicate that $F$ and $B$ are present in greater quantity than $\mathrm{E}$ or $\mathrm{A}$. Thus, Morris and Williams (16) using micro-polarographic technics have presented evidence indicating the concentration of $F$ and $B$ in peripheral blood to be about twice that of $E$ and $A$, while Bush and Sandberg (17) find evidence only for F and B.

The factors affecting the rate and type of adrenocortical secretion, in particular the species variation, has recently been reviewed by Bush (18). The values reported by Hechter (19) using perfused bovine adrenals would suggest that $F$ and $B$ were the chief alpha-ketolic steroids at least in that species. The extensive studies of Pincus, Romanoff, and Romanoff (20) using perfused, isolated human adrenals from subjects with malignant hypertension or prostatic carcinoma indicate the presence of 25 alpha-ketolic steroids after stimulation by ACTH. Evidence

on the chromatogram. The diagonally-lined peaks indicate those peaks in which identification studies included sulfuric acid chromogens $/ / /$, and infrared spectroscopy 111 , or both $\$ 808$. Only those compounds in which the studies included one or both of these technics are considered to be identified. The abbreviations (see Table I) above the diagonally-lined peaks indicate the identity of the steroid. The numbers on the peaks may be used in referring to the identification studies listed in Table I. The numbers in the columns on the right show the values for various group reactions.

AKSM = Total alpha-ketolic steroid metabolites. The semi-quantitative estimate of alphaketolic metabolites is obtained from the area of the blue tetrazolium staining peaks and the proportion of the extract of the 24-hour urine collection on the chromatogram (1).

G'ase $\mathrm{R}-\mathrm{L}=$ Reducing lipid-soluble substances (corticoids) after glucuronidase followed by acid hydrolysis.

Ac. $\mathrm{R}-\mathrm{L}=$ Reducing lipid-soluble substances after acid hydrolysis only.

$17 \mathrm{KS}=$ Total neutral $17-$ ketosteroids.

For comment concerning identity of peak No. 5, subject HI. after ACTH, see text. 

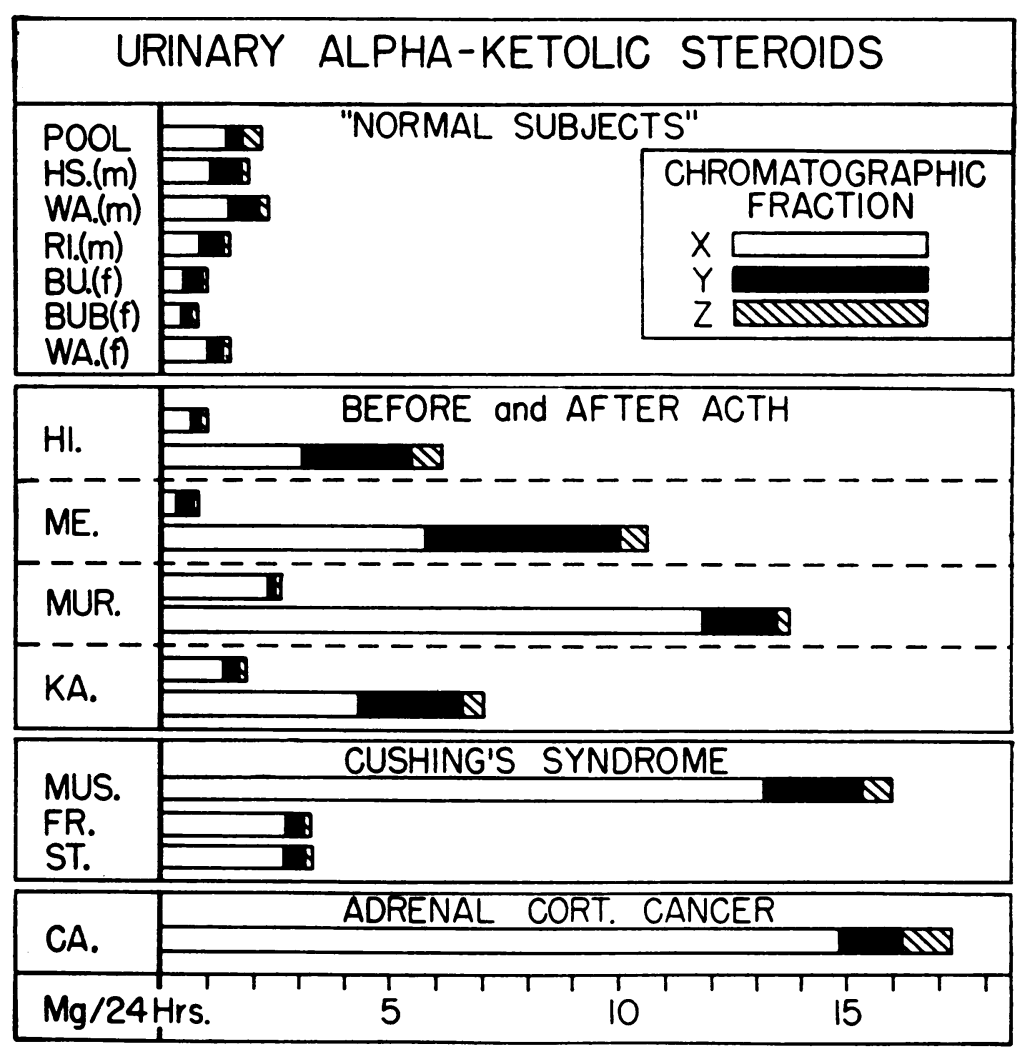

Fig. 2. Semi-Quantitative Estimations of the Urinary Alpha-Ketolic Steroid Metabolites Found in the Most Polar (X), Mid-Polar (Y) and Least Polar (Z) Fractions under Various Conditions

Note the relatively greater amount in the $X$ fraction compared to the $Y$ and $Z$ fractions in the subjects with Cushing's syndrome. For identification studies see Table $I$ and Figures 1 and 3 ; and for semi-quantitative estimates of individual metabolites see Table II.

for the presence of $\mathrm{F}$ and $\mathrm{B}$ and $\mathrm{S}$ as well as certain ring A saturated compounds was obtained, but the predominance of corticosterone and hydrocortisone seen in bovine adrenal perfusates was not found. However, preliminary studies of Touchstone, Cooper, and Roberts (21) using incubated slices of adrenals from hypertensive humans removed at operation indicate that $\mathrm{F}$ and $\mathrm{B}$ are usually the major alpha-ketolic secretory products. Undoubtedly, in vitro studies and studies of peripheral blood and of urine afford only indirect evidence. Thus the exact solution of the problem awaits further study of blood from the adrenal vein of humans.

Speculations concerning secretion rates. Certain speculations concerning the probable daily secretion rate by the adrenal cortex of compounds $\mathrm{F}$ or $\mathrm{E}$ and of compounds $\mathrm{B}$ or $\mathrm{A}$ have been made
(Table IV). These speculations are based on calculations derived from previous experiments in which the urinary alpha-ketolic steroid metabolites were measured following the oral administration of these steroids to individuals with adrenal cortical insufficiency (1). The proportion of orally administered alpha-ketolic steroid metabolites appearing in the urine as alpha-ketolic metabolic products was calculated from these data. The means of these values for each orally administered precursor were then utilized to calculate the theoretical secretion rates for compounds $F$ or $E$ from the urinary alpha-ketolic steroid metabolites found in chromatographic fraction $\mathrm{X}$; and for compounds B or A from the alpha-ketolic metabolites found in chromatographic fraction $\mathrm{Y}$ plus $Z$ of the experiments listed in Table IV. It has been previously demonstrated that almost all 
of the alpha-ketolic steroid metabolites from compounds $F$ or $E$ are found in fraction $X$ and those from compounds $B$ or $A$ in fractions $Y$ plus $Z$.

The assumptions implicit in these speculative calculations are undoubtedly only partially true. However, several considerations lead us to believe that they are not without some validity. These are: (a) The secretory rate, calculated on the assumption that either $\mathrm{F}$ or $\mathrm{E}$ is secreted, grossly approximates the amount of these compounds found necessary to maintain totally adrenalectomized individuals in fairly good health (22) ; (b) the calculated secretory rates of $\mathrm{F}$ or $\mathrm{E}$ for the two individuals with moderately severe Cushing's syndrome is in the range of dosages which, if continued for months, may produce this syndrome in individuals given $\mathrm{F}$ or $\mathrm{E}$ for therapeutic purposes $(23,24)$; (c) the ratio of calculated $\mathrm{F}$ to $\mathrm{B}$ secretion in normal individuals, and the ratio for those given ACTH for one day, are similar to those reported by Bush and Sandberg (17). In their study of peripheral blood of individuals given $\mathrm{ACTH}$, the ratio of $\mathrm{F}$ to a compound tentatively identified as $B$ was $\geqslant 4$ and for untreated individuals was $\geqslant 5$. However, the cal- culated ratio is somewhat less than the $F$ to $B$ ratio of 11 for material isolated from adrenal vein blood by Romanoff, Hudson, and Pincus (15); and greater than the approximately 1 to 1 ratio found by Morris and Williams for peripheral blood (16); (d) there is a higher calculated ratio of $\mathrm{F}$ to $\mathrm{B}$ secretion in the individual given $\mathrm{ACTH}$ on three days and in the three individuals with Cushing's syndrome than that of the untreated individuals or those given ACTH for one day. This may be compared to the findings of Kass, Hechter, Macchi, and Mou (25) of an increasing ratio of $F$ to $B$ in the peripheral blood of rabbits which were injected with ACTH up to periods of four weeks. In addition, Bush (26) has found a plasma $F$ to " $B$ " ratio of 20 to 1 in adrenal vein blood of a patient with Cushing's syndrome; a figure that compares quite well with the calculated production ratios of these compounds in our three patients with Cushing's syndrome.

Considerations concerning allopregnane derivatives. Engel, Carter, and Springer (12) have presented evidence that allo- $\mathrm{H}_{4} B$ (allopregnane- $3 \alpha$, $11 \beta, 21$-triol-20-one) is one of the major alphaketolic metabolites of compound $B$, and we have

TABLE II

Identified and some indicated (partially identified) urinary $\alpha$-ketolic metabolites: semi-quantitative estimation (mg. per $24 \mathrm{hr}$.) *

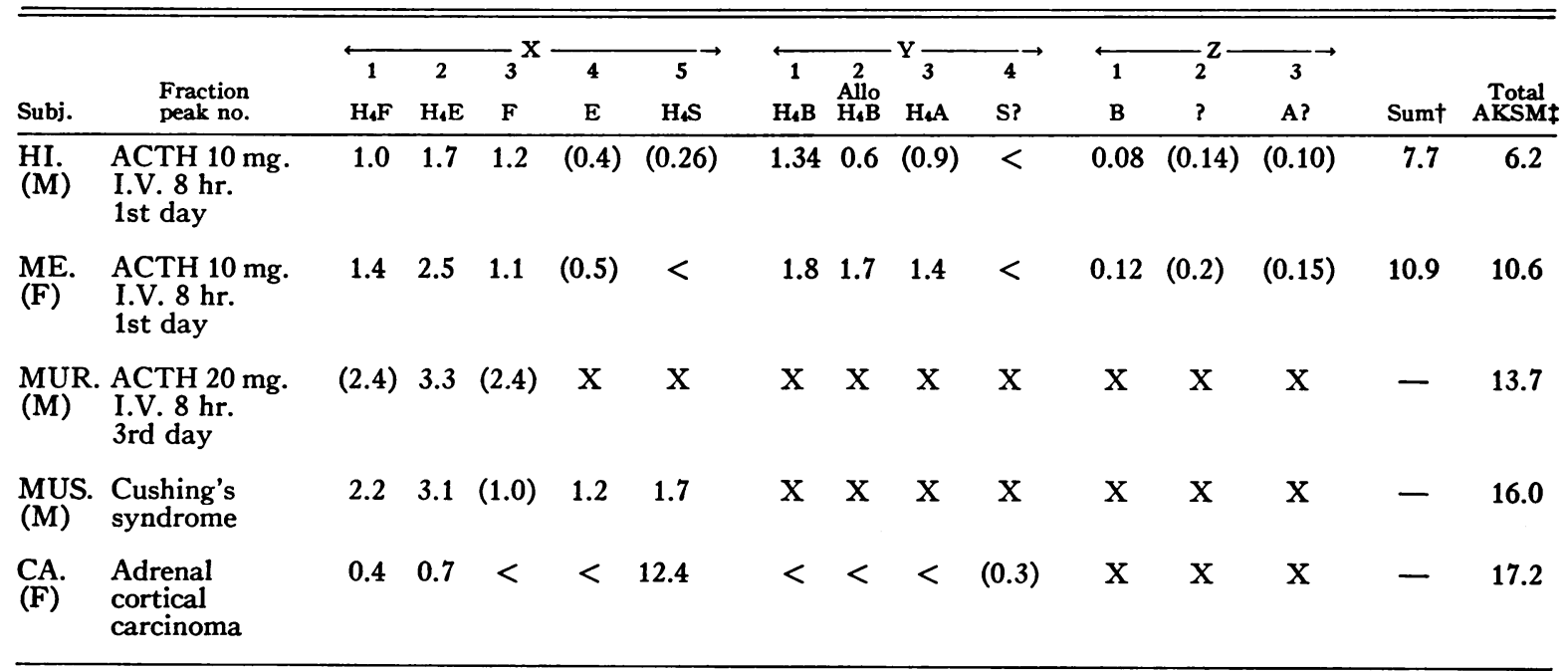

* $\mathrm{X}=$ Possibly present but not estimated, not rechromatographed.

$<=$ No alpha-ketolic peak at appropriate position at level tested.

$($ ) = Partial identification only; suspected identity indicated. (See Table I and text.) The identification procedures for those substances, the values for which are not enclosed in parentheses, included spectrometry in $\mathrm{H}_{2} \mathrm{SO}_{4}$ or infrared spectrometry or both as well as other studies listed in Table $\mathrm{I}$. t Sum of estimates of individual alpha-ketolic metabolites found on rechromatography.

$\ddagger$ Estimate of total alpha-ketolic metabolites from original chromatogram (includes unidentified blue tetrazolium staining peaks). 
TABLE III

Alpha-ketolic steroid metabolites extracted from urine of humans without adrenocortical dysfunction *

\begin{tabular}{|c|c|c|}
\hline Alpha-ketolic steroid & Condition & References and comments \\
\hline $\mathrm{H}_{4} \mathrm{~F}$ “Tetrahydro compound F" & After ACTH & Dobriner and Lieberman $1952(39) \dagger$ \\
\hline Pregnane-3 $\alpha, 11 \beta, 17 \alpha, 21$-tetrol-20-one & $\overline{\text { Normal }}$ & Romanoff et al. $1953(38)$ and $(40)$ \\
\hline $\mathrm{H}_{4} \mathrm{E}$ "Tetrahydro compound E" & After ACTH & Dobriner and Lieberman $1952(39) \dagger$ \\
\hline Pregnane-3 $\alpha, 17 \alpha, 21$-triol-11, 20-dione & Normal & Schneider 1952 (41) and $(30)(38)(40)(42)$ \\
\hline F "Hydrocortisone" & After ACTH & Mason 1950 (43) and (39)† \\
\hline$\Delta^{4}$-pregnene-11 $\beta, 17 \alpha, 21$-triol-3, 20-dione & Normal & Schneider 1952 (41) and (38) $(40)(42)$ (44) \\
\hline E "Cortisone" & After ACTH & Dobriner and Lieberman 1952 (39) \\
\hline$\Delta^{4}$-pregnene-17 $\alpha, 21$-diol-3, 11, 20-trione & Normal & Schneider 1950 (45) and (38) (40) (42) (44) \\
\hline $\begin{array}{l}\mathrm{H}_{2} \mathrm{E} \text { "Dihydro compound } \mathrm{E} " \\
\text { Pregnane-17 } \alpha, 21 \text {-diol-3, 11, 20-trione }\end{array}$ & Normal & Schneider 1952 (41) \\
\hline$\Delta^{6}$-pregnene-3 $\beta, 21$-diol-20-one & After ACTH & Dobriner and Lieberman 1952 (39) \\
\hline $\begin{array}{l}\mathrm{H}_{4} \mathrm{~S} \text { "Tetrahydro compound S" } \\
\text { Pregnane-3 } \alpha, 17 \alpha, 21 \text {-triol-20-one ? }\end{array}$ & $\begin{array}{l}\text { Normal after } \\
\text { ACTH }\end{array}$ & 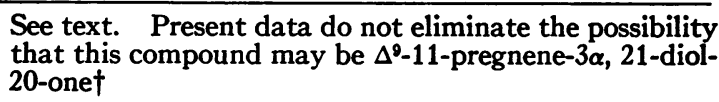 \\
\hline
\end{tabular}

Aldosterone (electrocortin)

Nephrosis

$11 \rightarrow 18$ hemiacetal of

$\Delta^{4}$-pregnene-11 $\beta, 21$-diol-18-al-3, 20-dione

(Adrenal dysfunction ?)

\begin{tabular}{|c|c|c|}
\hline $\begin{array}{l}\text { H,B "Tetrahydro compound B" } \\
\text { Pregnane-3 } \alpha, 11 \beta, 21 \text {-triol-20-one }\end{array}$ & $\begin{array}{l}\text { Normal after } \\
\text { ACTH }\end{array}$ & Touchstone et al. $1954(7) \dagger$ \\
\hline $\begin{array}{l}\text { Allo-H }{ }_{4} B \text { "Allotetrahydro compound B" } \\
\text { Allopregnane- } 3 \alpha, 11 \beta, 21 \text {-triol-20-one }\end{array}$ & $\begin{array}{l}\text { Normal after } \\
\text { ACTH }\end{array}$ & Touchstone et al. $1954(7) \dagger$ \\
\hline $\begin{array}{l}\text { H,A "Tetrahydro compound A" } \\
\text { Pregnane-3 } \alpha, 21 \text {-diol-11, 20-dione }\end{array}$ & $\begin{array}{l}\text { Normal after } \\
\text { ACTH }\end{array}$ & Touchstone et al. $1954(7) \dagger$ \\
\hline $\begin{array}{l}\text { B "Corticosterone" } \\
\Delta^{4} \text {-pregnene-11 } \beta, 21 \text {-diol-3, 20-dione }\end{array}$ & $\begin{array}{l}\text { Normal after } \\
\text { ACTH }\end{array}$ & $\begin{array}{l}\text { Touchstone et al. } 1954(7) \dagger \\
\text { Evidence indicating presence of B in urine of untreated } \\
\text { humans obtained by Romanoff et al. (38) }\end{array}$ \\
\hline
\end{tabular}

* Identification technics for the named references included identification by classical methods and/or by infrared spectrophotometry. The additional references included these technics in some, but not all instances.

† Identification reported in this paper. See Table I.

discussed evidence suggesting that this compound is one of the metabolites of compounds $B$ and $A$ (1). The finding of allo- $\mathrm{H}_{4} \mathrm{~B}$ after ACTH, (7) is probably best explained on the basis of metabolic reduction of compound $B$ rather than direct production of allo- $\mathrm{H}_{4} \mathrm{~B}$ by the cortex. This seems probable since allopregnane-3 $\alpha, 11 \beta, 21$-triol-20-one has not been identified in adrenal extracts although the $3 \beta$ isomer has been isolated in relatively small amounts and all the ring $A$ saturated alpha-ketols so far identified have had the allo configuration (13).

\section{Part II. Pathological Increases in Adrenal Cor- tical Activity}

The paper chromatographic patterns of alphaketolic steroid metabolites were studied in three individuals with Cushing's syndrome and one with adrenal cortical carcinoma.

\section{Cushing's syndrome-Case histories}

Case No. 1. Subject MUS. This 19-year-old man had typical florid Cushing's syndrome with onset approximately three years before he was referred for further study to the Hospital of the University of Pennsylvania from the Delaware Hospital, Wilmington. There was no evidence, by $x$-ray, of adrenal, pituitary or thymic tumors. Urine was collected prior to roentgen therapy.

Case No. 2. Subject ST. This 45-year-old housewife had increasing hirsutism (enough to require daily shaving), chronic leg ulcers, easy bruising, a large relaxed abdomen, no purple striae, and a red, rounded face for about two and one-half years prior to her study. At Wilkes-Barre Hospital, where she was found to have diabetes mellitus and severe hypertension $(200 / 120 \mathrm{~mm}$. $\mathrm{Hg}$ ), the diagnosis of Cushing's syndrome was made. She was referred to the Hospital of the University of 
Pennsylvania where no evidence of adrenal cortical tumor was found. She received 4,550 tissue roentgens to the pituitary region over 85 days. Urine collections for chromatography were made 77 days after the last roentgen treatment. She showed no improvement, developed pyelonephritis and died with pulmonary edema and necrotizing papillitis three months after the last roentgen treatment. The adrenals weighed 24 grams and showed histological evidence of hyperplasia of the cortex but no evidence of tumor. The anterior pituitary showed an increase in basophilic cells.

Case No. 3. Subject FR. This 45-year-old housewife suffered from a severe suicidal depression. She had shown gradually increasing evidence of the development of Cushing's syndrome during the previous four years. There was rounding of the face which was a dusky, brown-red color, multiple "bruises," no purple striae, moderate hirsutism, blood pressure of $170 / 110 \mathrm{~mm} . \mathrm{Hg}$, a glucose tolerance curve as follows: fasting -85 , onehalf hour-180, one hour-184, two hours-162, and three hours-91 mg. per $100 \mathrm{ml}$. of blood, increased 17-ketosteroids and corticoid excretion (after acid hydrolysis), and loss of menses at age 41 . There was no $x$-ray evidence of adrenal cortical tumor. No therapy had been given prior to the collection of urine for chromatography.

Identification studies and chromatographic pattern (Cushing's syndrome)

Table $I$ and Figure 3 show that $\mathrm{H}_{4} \mathrm{~F}, \mathrm{H}_{4} \mathrm{E}, \mathrm{E}$, and $\mathrm{H}_{4} \mathrm{~S}$ were identified in extracts of the urine of MUS., the male subject with florid Cushing's syndrome. In addition, large amounts of $\mathrm{F}$ were indicated, as partially identified by $R_{D O C}$, ultraviolet light absorption, positive Porter-Silber test and fluorescence in sulfuric acid. Table II gives the approximate amounts of the identified and partially identified compounds.

Figure 3 demonstrates the chromatographic patterns in subjects with hyperfunction of the adrenal cortical tissue, i.e., three patients with Cushing's syndrome (without adrenocortical tumor) and a patient with functioning metastases from adrenal cortical carcinoma. The general similarity of the chromatographic patterns of the individuals with Cushing's syndrome to those of the patients receiving ACTH is apparent, particularly that of subject MUR. who received ACTH for three days (compare Figures 1 and 3 ). The peak at the $F$ position was present in all three patients with Cushing's syndrome as were the peaks in the $\mathrm{H}_{4} \mathrm{~F}$ and $\mathrm{H}_{4} \mathrm{E}$ positions. In addition, there were relatively large amounts of AKSM present at the $\mathrm{E}$ position in all three individuals with Cushing's syndrome using a proportion of the 24-hour urine specimen which usually failed to show an alpha-ketolic peak at this position with urine extract from "normal" individuals. However, some of this peak in subjects FR. and ST. may be due to the presence of $\mathrm{H}_{4} \mathrm{~S}$, since in sub-

TABLE IV

Speculations concerning approximate secretion rates *

\begin{tabular}{|c|c|c|c|c|c|c|c|c|}
\hline & & & & \multicolumn{5}{|c|}{ Calculated secretion rate } \\
\hline & \multicolumn{3}{|c|}{ Urinary AKSM } & \multicolumn{2}{|c|}{$\begin{array}{l}\text { As if all } \\
X \text { fraction }\end{array}$} & \multicolumn{2}{|c|}{$\begin{array}{c}\text { As if all } \\
Y+Z \text { fraction }\end{array}$} & \multirow{4}{*}{$\begin{array}{c}\begin{array}{c}\text { F/B } \\
\text { ratio }\end{array} \\
6\end{array}$} \\
\hline & \multirow{2}{*}{$\begin{array}{c}\text { Total } \\
m s . / 24 \text { hr. }\end{array}$} & \multicolumn{2}{|c|}{$\begin{array}{c}\text { Fraction X } \\
\text { \% of total AKSM } \\
\end{array}$} & \multirow{2}{*}{\multicolumn{2}{|c|}{$\begin{array}{c}\text { From } \underset{E}{\text { From }} \\
\text { mg./24 hr. }\end{array}$}} & \multirow{2}{*}{\multicolumn{2}{|c|}{$\begin{array}{l}\text { From } \underset{\text { From }}{\text { B }} \\
\text { mg./24 hr. }\end{array}$}} & \\
\hline & & Mean & Range & & & & & \\
\hline Normal (9) $\dagger$ & 1.4 & 64 & $57-71$ & 68 & 37 & 11 & 7 & \\
\hline $\begin{array}{l}\text { ACTH } 10 \mathrm{mg} . \text { (3) } \\
\text { I.V. } 8 \text { hrs. 1st day } \\
\text { (24-hr. collection) }\end{array}$ & 8.3 & 56 & $50-63$ & 329 & 180 & 77 & 50 & 4 \\
\hline $\begin{array}{l}\text { ACTH } 20 \mathrm{mg} \text { (1) } \\
\text { I.V. } 8 \text { hrs. 3rd day } \\
\text { (24-hr. collection) }\end{array}$ & 13.7 & 86 & 一 & 885 & 483 & 39 & 27 & 23 \\
\hline $\begin{array}{l}\text { Cushing's syndrome } \\
\text { severe (1) }\end{array}$ & 16.0 & 83 & - & 990 & 540 & 61 & 40 & 16 \\
\hline $\begin{array}{l}\text { Cushing's syndrome } \\
\text { moderate (2) }\end{array}$ & 3.2 & 88 & $88-88$ & 210 & 131 & 9 & 6 & 23 \\
\hline
\end{tabular}

* Since $F$ and $E$, as well as $B$ and $A$, are interconvertible, separate rates are calculated on the assumption that all $\mathrm{X}$ fraction represents the metabolites of either $\mathrm{F}$, or of $\mathrm{E}$, and that all of the $\mathrm{Y}+\mathrm{Z}$ fraction represents the metabolites
of either $B$, or of $A$. (Also see text.)

$\dagger$ The numbers in parentheses indicate the number of subjects. 


\section{CHROMATOGRAPHIC PATTERN: ALPHA-KETOLIC STEROID METABOLITES} CUSHING'S SYNDROME
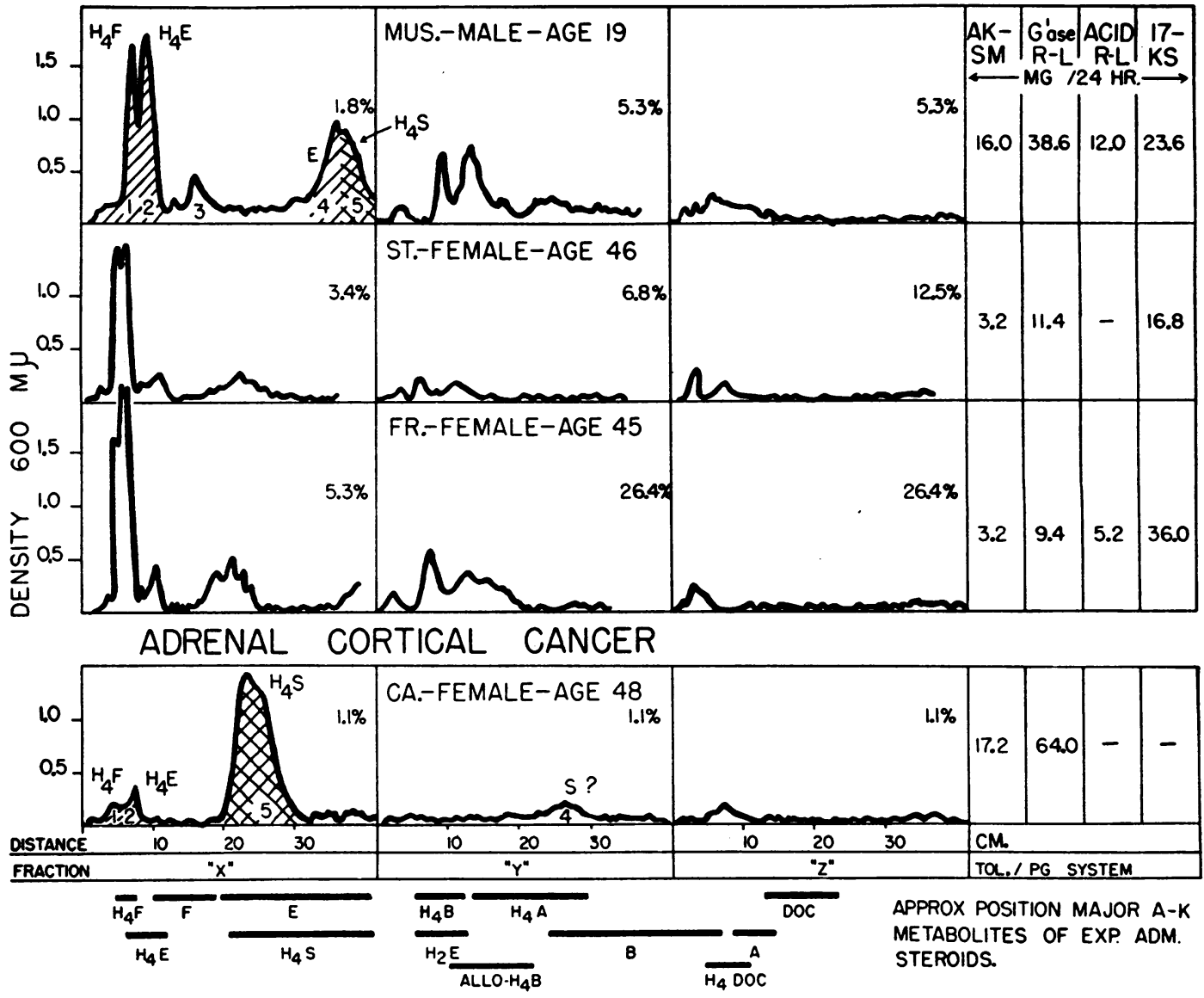

Fig. 3. The Chromatographic Pattern of the Alpha-Ketolic Steroids Excreted in the Urine of Three Individuals with Cushing's Syndrome and One with Adrenocortical Carcinoma

See legend, Figure 1, for explanation of charting technic and Table I for identification studies. The similarity of pattern (particularly the presence of the relatively large peak at the $F$ position in all three patients with Cushing's syndrome) to the chromatograms of normal and hypertensive subjects after ACTH (see Figure 1) should be noted.

Some of the fractions used in these studies were developed on slightly longer strips for a longer period while others were developed over a shorter period than usual. Therefore, there is a wider range of position of known metabolites as indicated by the lengths of the bars at the bottom of the chart.

ject MUS. approximately 60 per cent of this double peak $\left(\mathrm{X}_{4}\right.$ and $\left.\mathrm{X}_{5}\right)$ was due to $\mathrm{H}_{4} \mathrm{~S}$.

\section{Comment}

Identified alpha-ketolic steroid metabolites. The identification of $\mathrm{H}_{4} \mathrm{~F}, \mathrm{H}_{4} \mathrm{E}, \mathrm{E}$, and $\mathrm{H}_{4} \mathrm{~S}$ in the urine of a subject with Cushing's syndrome (MUS.) is in accord with the finding of the first three steroids in the urine of normal subjects with or without administration of ACTH (Table III).
Mason and Sprague (27) first identified hydrocortisone in the urine of a subject with Cushing's syndrome. Others have also reported its presence $(28,29)$ as well as $\mathrm{H}_{4} \mathrm{~F}(29), \mathrm{H}_{4} \mathrm{E}(28-30)$ and cortisone $(28,29)$ in the urine of subjects with this condition. Bush (26) has reported the presence of $F$ and $B$ in adrenal vein blood of a subject with Cushing's syndrome in a ratio of 20 to 1 (compare calculations in Table IV).

Evidence suggesting a change in adrenal cor- 
tical secretion pattern in subjects with Cushing's syndrome. The total AKSM (Figure 2) as measured by the areas underneath the curves is greater in the case of subject MUS. than that found after the infusion of ACTH (Figure 1); and greater in the other two subjects with Cushing's syndrome than that found in normal individuals not given ACTH. However, the proportion of alpha-ketols present (Figure 2 and Table IV) in the most polar fraction (X) in patients with Cushing's syndrome (range $=83$ to 88 per cent of total) is greater than that found in the urine of normal individuals (range $=57$ to 71 per cent of total), and of those given ACTH on one day only (range $=50$ to 63 per cent of total). On the other hand, it is not greater than the proportion in chromatographic fraction $\mathrm{X}$ from urine collected from MUR. on the third day of ACTH injection ( 86 per cent).

This finding in subject MUR. suggests, in addition to several other possibilities, that there may be an increase in the relative quantities of $F$ and/ or $\mathrm{E}$ secretion compared to that of $\mathrm{B}$ and/or $\mathrm{A}$ with more prolonged stimulation by ACTH. That there may be a change in the ratio of the precursors is suggested by the recent work of Kass, Hechter, Macchi, and Mou (25). They demonstrated an increase of compound $\mathrm{F}$ and a progressive decrease in compound $B$ in the adrenal vein blood of rabbits measured at the 7 th, and the 21st to 28th day of ACTH injection. These considerations suggest that the higher proportion of steroid metabolites in the most polar fraction $(X)$ in the chromatograms of urinary extracts from patients with Cushing's syndrome, found by ourselves and Wilson, Fairbanks, and Scialabba (29) is due to an increase in the secretion ratio of $F$ and/or $E$ to $B$ and/or $A$ (see Table IV). They also suggest that this change is presumably due to prolonged stimulation by greater than usual amounts of ACTH. However, measurements of blood levels of ACTH in this condition have given widely varying results (31), although recently Rubin, Dorfman, and Dorfman (32) has reported a significant increase of ACTH excretion in the urine of an individual with Cushing's syndrome.

There was an absolute increase in excretion of fractions $Y$ and $Z$ (indicating an increase in the metabolic products of $B$ or $A$ ) in the subject
MUS. with florid Cushing's syndrome, but this was not found in subjects FR. or ST. in whom the manifestations were less marked. Speculations from these findings concerning probable secretion rates of the adrenal cortex in Cushing's syndrome are presented in the Comments, Part I, and in Table IV.

\section{Adrenal cortical carcinoma-Case history}

Subject CA. This case has previously been reported in detail (33). The finding in her urine of pregnane-3 $\alpha$, $17 \alpha, 21$-triol-20-one ( $\mathrm{H}_{4} \mathrm{~S}$ - "tetrahydro compound $\mathrm{S}$ ") has also been previously reported (34) and electrolyte balance studies have been presented by Elkinton, Squires, and Crosley (35). This 48-year-old housewife showed marked hirsutism, acne, low pitched voice, enlarged clitoris, atrophy of the breasts, and marked muscular weakness, associated with abnormalities of electrolyte metabolism at times similar to those found in Cushing's syndrome, but had periods of hypoglycemia (prior to, and after development of recognizable liver metastases). The urine for chromatography was collected one month before her death with metastases eight months after removal of the original tumor. At approximately this time, the total neutral 17-ketosteroid excretion varied between 162 and $320 \mathrm{mg}$. per $24 \mathrm{hr}$. The urinary estrogens were considerably elevated, by bioassay (greater than 400 and less than 660 mouse units per 24 hrs.). Neutral lipid-soluble reducing substances found in the extract subjected to paper chromatography totaled $64 \mathrm{mg}$. per $24 \mathrm{hr}$. (Values in normal individuals by the method used are usually less than $20 \mathrm{mg}$. per $24 \mathrm{hrs}$.)

\section{Chromatographic pattern and identification studies (adrenal cortical carcinoma)}

The alpha-ketolic peak produced by tetrahydro compound $\mathrm{S}$ in the $\mathrm{X}$ fraction of the chromatogram is shown in Figure 3 and identification studies listed in Table I. A semi-quantitative estimate (Table II) indicates that approximately 12.4 mg. of tetrahydro compound $S$ were extractable (by the method used) from the 24-hour urine collection. In addition, a small amount of material with many of the characteristics of compound $S$ was isolated (see Tables I and II). The identification procedures listed in Table I for the suspected compound $S$ do not include spectrometry in sulfuric acid or infrared spectrometry since insufficient material was obtained from the aliquot of the 24-hour urine specimen employed. However, the development of a red color in sulfuric acid (36) in association with running rates $\left(R_{D O C}\right)$, absorption of ultraviolet light and positive 
Porter-Silber reaction all indicate that the substance may be Reichstein's compound S.

\section{Comment}

As previously reported (1), the administration of $100 \mathrm{mg}$. of $\mathrm{S}$ acetate on three occasions to two subjects with markedly decreased adrenocortical function resulted in an average urinary excretion of $2.1 \mathrm{mg}$. of AKSM per $24 \mathrm{hrs}$; ; over 90 per cent of this was $\mathrm{H}_{4} \mathrm{~S}$. Although the amount of alphaketols excreted is apparently not a straight-line function of the dose administered, calculations from the above suggest that this patient was excreting metabolites equivalent to that resulting from oral ingestion of approximately $600 \mathrm{mg}$. of compound S per day. Since (a) the production of compounds $F$ (and/or $E$ ) appeared to be within normal limits in the subject CA. as judged by the excretion of $\mathrm{H}_{4} \mathrm{~F}$ and $\mathrm{H}_{4} \mathrm{E}$ in "normal" amounts, and (b) at post-mortem the remaining adrenal was normal histologically and not atrophic (wt. = 7 gm.), it would appear likely that this remaining adrenal might have accounted for the hypothesized normal rate of production of $F$ (and/ or $\mathrm{E})$.

The production of ACTH was apparently not significantly inhibited, since the remaining adrenal was not atrophic. This is in agreement with the previously demonstrated weak ACTH suppressing effect of compound $S$ in the rat (37). It would also seem probable that the major alpha-ketolic steroid produced by the metastatic adrenal carcinoma was compound S. Hechter (19) has postulated the production of compound $S$ as an intermediate in the production of $\mathrm{F}$ from 17-hydroxyprogesterone (19). It seems probable that the introduction of a hydroxyl group at carbon atom 11 did not take place, but that 21-hydroxylation did occur in this particular cancer tissue. This concept is in accord with the view that cancer cells are more "primitive" in nature and hence might not contain all the enzyme systems present in mature cells. The possibility exists, however, that specific adrenal cortical cells might have such a restricted function.

The subject's electrolyte pattern may be explained on the basis of secretion of large amounts of compound $\mathrm{S}$ but the hypoglycemia and very large amounts of neutral 17-ketosteroids and "dehydroepiandrosterone" (33) in the urine cannot be explained on this basis alone (22). In addition, the chromatographic evidence of "normal" amounts of $\mathrm{H}_{4} \mathrm{~F}$ and $\mathrm{H}_{4} \mathrm{E}$ would seem to indicate a relatively normal amount of $\mathrm{F}$ and/or $\mathrm{E}$ secretion; so, apparently, the hypoglycemia was not due to an absolute insufficiency of $F$ (or $\mathrm{E})$, unless there was a considerable decrease in secretion from time to time.

\section{DISCUSSION}

Three previously identified and four "new" alpha-ketolic steroid metabolites have been identified in the urine of subjects given intravenous $\mathrm{ACTH}$ and four metabolites in a subject with Cushing's syndrome and three in a subject with adrenocortical carcinoma. Comments after Parts I and II present certain speculations concerning the probable precursors of these alpha-ketolic metabolites.

Table III lists a total of 11 alpha-ketols that have been identified in the urine of individuals without adrenocortical disease. However, it is emphasized that many more as yet unidentified alpha-ketols are present in lesser amounts, as indicated by the studies of Romanoff, Wolf, Constandse, and Pincus (38).

\section{SUMMARY AND CONCLUSIONS}

1. The following urinary alpha-ketolic steroid metabolites have been identified by chromatographic studies and spectrometry in sulfuric acid or infrared spectrometry or both following ACTH infusion to humans: $\mathrm{H}_{4} \mathrm{~F}$ (Pregnane- $3 \alpha, 11 \beta, 17 \alpha$, 21-tetrol-20-one), $\mathrm{H}_{4} \mathrm{E}$ (Pregnane-3 $\alpha, 17 \alpha, 21$ triol-11, 20-dione), F ( $\Delta^{4}$-pregnene-11 $\beta, 17 \alpha, 21$ triol-3, 20-dione), the first three having been previously identified by others; plus $\mathrm{H}_{4} B$ (Pregnane-3 $\alpha, 11 \beta, 21$-triol-20-one), allo- $\mathrm{H}_{4} \mathrm{~B}$ (Allopregnane-3 $\alpha, 11 \beta, 21$-triol-20-one), $\mathrm{H}_{4} \mathrm{~A}$ (Pregnane-3 $\alpha, 21$-diol-11, 20-dione), and B ( $\Delta^{4}$-pregnene-11 $\beta, 21$-diol-3, 20-dione).

2. The first three compounds have previously been identified as metabolites of $F$ and $E$, and the last four as metabolites of B and A. Since B and $A$, as well as $F$ and $E$, are interconvertible, even in individuals with severely impaired adrenal function, deductions from peripheral blood or urine studies concerning the specific adrenal cor- 
tical precursor of the respective metabolites of these two pairs are difficult. Some of the evidence concerning adrenocortical secretion has been presented. It suggests that $F$ and $B$ are probably secreted in greater quantities than other compounds.

3. The finding of allo- $\mathrm{H}_{4} \mathrm{~B}$ as a urinary metabolite after ACTH infusion has been discussed in the light of recent evidence indicating this to be one of the major metabolites of compound $B$.

4. Pregnane-3 $\alpha, 17 \alpha, 21$-triol-20-one $\left(\mathrm{H}_{4} \mathrm{~S}\right)$ has been found in the urine of a man with Cushing's syndrome and in large amounts in the urine of a woman with metastatic adrenocortical carcinoma. The implications are discussed.

5. The similarity of the chromatographic pattern of the alpha-ketolic steroid metabolites found in urine extracts of individuals with Cushing's syndrome to that found after three days of $\mathrm{ACTH}$ infusion is presented. The difference in chromatographic pattern between these subjects and those individuals given ACTH for only one day is noted, and implications concerning a possible change in secretion with prolonged stimulation by $\mathrm{ACTH}$ discussed.

6. The semi-quantitative values obtained for specific, identified, and partially identified alphaketolic metabolites, as well as estimations (by group reaction technics) of the total alpha-ketolic steroid metabolites (AKSM), reducing lipids (corticoids) after acid hydrolysis (Acid R-L) and after glucuronidase plus acid hydrolysis (G'ase $\mathrm{R}-\mathrm{L}$ ) and the 17-ketosteroids in normal individuals, individuals after ACTH and patients with Cushing's syndrome and adrenocortical carcinoma are presented.

\section{Addendum}

$\mathrm{H}_{4} \mathrm{~S}$ (Pregnane-3 $\alpha, 17 \alpha, 21$-triol-20-one), B ( $\Delta^{4}$-Pregnene-11 $\beta, 21$-diol-3, 20-dione) and A ( $\Delta^{4}$-Pregnene-21-ol-3, 11, 20-trione) have recently been identified (infrared spectrometry and spectrometry in $\mathrm{H}_{2} \mathrm{SO}_{4}$ and other tests) in extracts of the urine of a man receiving ACTH during an episode of rheumatic fever. This lends further support to the supposition that peak $\mathrm{X}_{5}$ of subject $\mathrm{HI}$. receiving $A C T H$ and $Z_{3}$ of $H I$. and ME. combined (see Table I) are in fact $\mathrm{H}_{4} \mathrm{~S}$ and $\mathrm{A}$, respectively.

\section{ACKNOWLEDGMENT}

We wish to acknowledge, with gratitude, the interest and support of Dr. C. C. Wolferth. We also wish to acknowledge the invaluable help of Dr. Thomas F. Gal- lagher through whose courtesy all infrared analyses were performed at the Sloan-Kettering Institute for Cancer Research, Memorial Center, New York.

\section{REFERENCES}

1. Richardson, E. M., Touchstone, J. C., and Dohan, F. C., Urinary alpha-ketolic steroid metabolites of cortical hormones administered to subjects with adrenal cortical insufficiency. J. Clin. Invest., 1955, 34, 285.

2. Burton, R. B., Zaffaroni, A., and Keutmann, E. H., Paper chromatography of steroids. II. Corticosteroids and related compounds. J. Biol. Chem., 1951, 188, 763.

3. Tennent, D. M., Whitla, J. B., and Florey, K., Two techniques in paper chromatography; application to ketosteroids. Anal. Chem., 1951, 23, 1748.

4. Heard, R. D. H., Sobel, H., and Venning, E. H., The neutral lipide-soluble reducing substances of urine as an index of adrenal cortical function. $\mathrm{J}$. Biol. Chem., 1946, 165, 699.

5. Holtorff, A. F., and Koch, F. C., The colorimetric estimation of 17-ketosteroids and their application to urine extracts. J. Biol. Chem., 1940, 135, 377.

6. Lieberman, S., Mond, B., and Smyles, E., Hydrolysis of urinary ketosteroid conjugates in Recent Progress in Hormone Research, edited by G. Pincus, New York, Academic Press Inc., 1954, vol. 9, p. 113.

7. Touchstone, J. C., Bulaschenko, H., Richardson, E. M., and Dohan, F. C., The isolation of pregnane$3 \alpha, 11 \beta, 21$-triol-20-one, allopregnane-3 $\alpha, 11 \beta, 21-$ triol-20-one, pregnane-3 $\alpha, 21$-diol-11, 20-dione and $\Delta^{4}$-pregnene-11 $\beta, 21$-diol-3, 20-dione from the urine of normal subjects treated with corticotropin. Arch. Biochem. \& Biophys., 1954, 52, 284.

8. Burstein, S., Savard, K., and Dorfman, R. I., The in vivo metabolism of hydrocortisone. Endocrinology, 1953, 53, 88.

9. Burstein, S., Savard, K., and Dorfman, R. I., The in vivo metabolism of cortisone. Endocrinology, 1953, 52, 448.

10. Burton, R. B., Keutmann, E. H., and Waterhouse, C., The conversion of cortisone acetate to other alpha-ketolic steroids. J. Clin. Endocrinol. \& Metab., 1953, 13, 48.

11. Lieberman, S., Katzenellenbogen, E. R., Schneider, R., Studer, P. E., and Dobriner, K., Isolation of urinary steroids after cortisone and adrenocorticotropic hormone. J. Biol. Chem., 1953, 205, 87.

12. Engel, L. L., Carter, P., and Springer, M. J., Isolation from urine of ketonic metabolites of administered corticosterone. Federation Proc., 1954, 13, 204 (and personal communications).

13. Dorfman, R. I., and Ungar, F., Metabolism of Steroid Hormones. Minneapolis, Burgess Publishing Co., 1953. 
14. Luetscher, J. A., Jr., Wettstein, A., and Neher, R., Isolation of crystalline aldosterone from the urine of a nephrotic patient. Experentia, In press.

15. Romanoff, E. B., Hudson, P., and Pincus, G., Isolation of hydrocortisone and corticosterone from human adrenal vein blood. J. Clin. Endocrinol. \& Metab., 1953, 13, 1546.

16. Morris, C. J. O. R., and Williams, D. C., Estimation of individual adrenocortical hormones in human peripheral blood, Vol. VII-Synthesis and Metabolism of Adrenocortical Steroids, Ciba Foundation Colloquia on Endocrinolgy, W. Klyne, ed., Boston, Little, Brown and Co., 1953, p. 261.

17. Bush, I. E., and Sandberg, A. A., Adrenocortical hormones in human plasma. J. Biol. Chem., 1953, 205, 783.

18. Bush, I. E., Species differences and other factors influencing adrenocortical secretion, Vol. VIISynthesis and Metabolism of Adrenocortical Steroids, Ciba Foundation Colloquia on Endocrinology, W. Klyne, ed., Boston, Little, Brown and Co., 1953, p. 210.

19. Hechter, O., Biogenesis of adrenal cortical hormones, Vol. VII-Synthesis and Metabolism of Adrenocortical Steroids, Ciba Foundation Colloquia on Endocrinology, W. Klyne, ed., Boston, Little, Brown and Co., 1953, p. 161.

20. Pincus, G., Romanoff, E. B., and Romanoff, L. P., Current status of corticosteroid metabolism in man, Vol. VII-Synthesis and Metabolism of Adrenocortical Steroids, Ciba Foundation Colloquia on Endocrinology, W. Klyne, ed., Boston, Little, Brown and Co., 1953, p. 240.

21. Touchstone, J. C., Cooper, D. Y., and Roberts, J. M., Steroid production by incubated human adrenal tissue. American College of Surgeons. Surgical Forum. In press.

22. Thorn, G. W., Jenkins, D., Laidlaw, J. C., Goetz, F. C., Dingman, J. F., Arons, W. L., Streeten, D. H. P., and McCracken, B. H., Pharmacologic aspects of adrenocortical hormones in man, and their effects in adrenal insufficiency in Medical Uses of Cortisone, F. D. W. Lukens, ed., New York, The Blakiston Co., Inc., 1954, p. 46.

23. Hench, P. S., and Ward, L. E., Rheumatoid arthritis and other rheumatic or articular diseases in Medical Uses of Cortisone, F. D. W. Lukens, ed., New York, The Blakiston Co., Inc., 1954, p. 177.

24. Hollander, J. L., Personal communication.

25. Kass, E. H., Hechter, O., Macchi, I. A., and Mou, T. W., Changes in patterns of secretion of corticosteroids in rabbits after prolonged treatment with ACTH. Proc. Soc. Exper. Biol. \& Med., 1954, 85, 583.

26. Bush, I. E., The paper chromatography of steroids and its application to assay problems, Vol. VBioassay of Anterior Pituitary and Adrenocortical Hormones, Ciba Foundation Colloquia on Endocrinology, G. E. W. Wolstenholme, ed., Boston, Little, Brown and Co., 1953, p. 203.
27. Mason, H. L., and Sprague, R. G., Isolation of 17hydroxycorticosterone from the urine in a case of Cushing's syndrome associated with severe diabetes mellitus. J. Biol. Chem., 1948, 175, 451.

28. Gray, C. H., and Lunnon, J. B., Some observations using a semiquantitative paper chromatographic method for the determination of urinary adrenocortical steroids in The Determination of Adrenocortical Steroids and Their Metabolites. P. Eckstein and S. Zuckerman, eds., London, Dennis Dobson Ltd., Soc. for Endocrinol. Mem. 2, 1953, 64.

29. Wilson, H., Fairbanks, R., and Scialabba, D., Quantitative pattern of urinary corticosteroids. J. Clin. Endocrinol., \& Metab., 1953, 13, 875 (abst.) and personal communication.

30. Baggett, B., Kinsella, R. A., Jr., and Doisey, E. A., Hydrolysis of conjugates of urinary corticoids with $\beta$-glucuronidase. II. The isolation and determination of tetrahydrocortisone. J. Biol. Chem., 1953, 203, 1013.

31. Paris, J., Upson, M., Jr., Sprague, R. G., Salassa, R. M., and Albert, A., Corticotropic activity of human blood. J. Clin. Endocrinol. \& Metab., 1954, 14, 597.

32. Rubin, B. L., Dorfman, R. I., and Dorfman, A., Adrenocorticotropic hormone (ACTH) in urine. J. Clin. Endocrinol. \& Metab., 1954, 14, 154.

33. Dohan, F. C., Rose, E., Eiman, J. W., Richardson, E. M., and Zintel, H., Increased urinary estrogen excretion associated with adrenal tumors: Report of four cases. J. Clin. Endocrinol. \& Metab., 1953, $13,415$.

34. Touchstone, J. C., Richardson, E. M., Bulaschenko, H., Landolt, I., and Dohan, F. C., Isolation of pregnane-3-alpha, 17-alpha, 21-triol-20-one (Tetrahydro compound $S$ ) from the urine of a woman with metastatic adrenocortical carcinoma. J. Clin. Endocrinol. \& Metab., 1954, 14, 676.

35. Elkinton, J. R., Squires, R. D., and Crosley, A. P., $\mathrm{Jr}$., Intracellular cation exchanges in metabolic alkalosis. J. Clin. Invest., 1951, 30, 369.

36. Reichstein, T., Uber Bestandteile der Nebennierenrinde. XXI. Die Konstitution der Substanzen R und S. Helvet. chim. Acta, 1938, 21, 1490.

37. Gaunt, R., Leathem, J. H., Howell, C., and Antonchak, N., Some biological properties of different esters of desoxycorticosterone. Endocrinology, 1952, 50, 521.

38. Romanoff, L. P., Wolf, R. S., Constandse, M., and Pincus, G., Analysis of urinary steroids following glucuronidase hydrolysis. I. Extraction and fractionation. J. Clin. Endocrinol. \& Metab., 1953, 13, 928.

39. Dobriner, K., and Lieberman, S., The metabolism of steroid hormones in humans, Vol. II-Steroid Metabolism and Estimation, Ciba Foundation Colloquia on Endocrinology, G. E. W. Wolstenholme, ed., Philadelphia, The Blakiston Co., 1952, p. 381. 
40. Cope, C. L., and Hurlock, B., The estimation of some adrenocortical products in urine in The Determination of Adrenocortical Steroids and Their Metabolites, P. Eckstein and S. Zuckerman, eds., London, Dennis Dobson Ltd., Soc. for Endocrinol. Mem. 2, 1953, 25.

41. Schneider, J. J., Further isolation of adrenocortical compounds from male urine. J. Biol. Chem., 1952, 194, 337.

42. DeCourcy, C., Bush, I. E., Gray, C. H., and Lunnon, J. B., A chromatographic investigation of $\Delta^{4}-3$ ketosteroids and $\alpha$-ketolic steroids in human urine. J. Endocrinol., 1953, 9, 401.
43. Mason, H. L., Isolation of adrenal cortical hormones from the urine: 17-hydroxycorticosterone and 17hydroxy-11-dehydrocorticosterone. J. Biol. Chem., 1950, 182, 131.

44. Burton, R. B., Zaffaroni, A., and Keutmann, E. H., Corticosteroids in urine of normal persons determined by paper chromatography. J. Biol. Chem., 1951, 193, 769.

45. Schneider, J. J., Studies on the excretion of adrenocortical compounds. I. Isolation of 17-hydroxy-11dehydrocorticosterone and other compounds from the urine of normal males. J. Biol. Chem., 1950, 183,365 . 